Kasbekar, D. K., Lavate, W. V., Rege, D. V. \& Sreenivasan, A. (1959b). Biochem. F. 72, $3^{84}$.

Ling, C. T. \& Chow, B. F. (1952). F. biol. Chem. 198, 439.

Ling, C. T. \& Chow, B. F. (1953). F. biol. Chem. 202, 445.

Luecke, R. W. \& Pearson, P. B. (1944). F. biol. Chem. I55, 507.

Mitbander, V. B. \& Sreenivasan, A. (1954). Arch. Mikrobiol. 21, 6o.

Mulgaonkar, A. G. \& Sreenivasan, A. (1957). Proc. Soc. exp. Biol., N.Y., 94, 44.

Mulgaonkar, A. G. \& Sreenivasan, A. (1958). Proc. Soc. exp. Biol., N.Y., 98, 652.

Nichol, C. A., Dietrich, L. S., Cravens, W. W. \& Elvehjem, C. A. (r949). Proc. Soc. exp. Biol., N.Y., 7o, 40 .

Pfander, W. H., Dietrich, L. S., Monson, W. J., Harper, A. E. \& Elvehjem, C. A. (1952). Proc. Soc. exp. Biol., N.Y., 79, 219.

Rao, T. B., Tamhane, D. V. \& Sreenivasan, A. (1958). In Antibiotics-A Symposium, p. 21 5. New Delhi: Council of Scientific and Industrial Research.

Register, U. D. (1954). F. biol. Chem. 206, 705.

Robbins, J. (1956). Arch. Biochem. Biophys. 63, 46r.

Robbins, J. \& Rall, J. E. (1955). F. clin. Invest. 34, 1324.

Rubin, M. \& Bird, H. R. (1947). F. Nutr. 34, 233.

Simkin, J. L. \& White, K. (1957). Biochem. F. 65, 574 .

Umbreit, W. W. (1946). In Manometric Techniques and Related Methods for the Study of Tissue Metabolism, p. ro3. [W. W. Umbreit, R. H. Burris and J. F. Stauffer, editors.] Minneapolis: Burgess Publishing Co.

Zucker, T. F. \& Zucker, L. M. (1950). Vitam. Ë Horm. 8, r.

\title{
The effect of oestrogens given by mouth on some aspects of the physiology of the newborn calf
}

\author{
By GILLIAN M. HAWKINS, J. H. B. ROY \\ AND K. W. G. SHILLAM \\ National Institute for Research in Dairying, Shinfield, Reading \\ AND J. C. GREATOREX ANd P. L. INGRAM \\ Royal Veterinary College, Camden Town, London, N.W. I \\ (Received 13 April 1959-Revised 12 August 1959)
}

During the last ro years many experiments have been made on the value of synthetic oestrogens, and to a lesser extent natural oestrogens and other steroid hormones, in stimulating the growth rate of cattle. Few reports are, however, available of experiments involving calves under I year of age. When 2 or $3 \mathrm{mg}$ stilboestrol/10o lb bodyweight were given to 4 -day-old calves, Voelker \& Dracy (I956) found no significant effect of treatment on weight gain, body measurements, food consumption or food utilization over a I I2-day period. Harris \& Rusoff (1956) gave stilboestrol or chlortetracycline or a combination of the two for the first 16 days of life; calves given the antibiotic grew at a faster rate than control animals, but there was no response with stilboestrol. The experiments reported in this paper were designed to observe the effect of giving oestrogens to the pre-ruminant calf.

The quantity of colostrum given in our experiments was reduced to an amount that would protect a calf from Escherichia coli septicaemia (Aschaffenburg, Bartlett, Kon, 
Roy, Sears, Thompson, Ingram, Lovell \& Wood, r953). Since the oestrogenic activity of bovine colostrum was found by Pope \& Roy (r953) to be equivalent to at least $9 \mu \mathrm{g}$ oestradiol-1 $7 \beta / 1$, the total amount of oestrogen, in the form of oestradiol, given over a 3 -week experimental period, was the same as might be normally ingested by a suckling calf during the same period of time. As there was no apparent physiological effect of oestradiol in the quantity used, a second experiment was done with a greater amount of the synthetic oestrogen stilboestrol ( 3,4 -di- $p$-hydroxyphenylhex-3-ene).

METHODS

\section{Plan of experiments}

The first experiment (Expt I) was done in the autumn of I954 and the second (Expt 2) in the autumn of 1955, the calfhouse having been left empty on each occasion since the spring. A randomized block design was used with two treatments in each of ten blocks for Expt 1 and in each of twelve blocks for Expt 2 thus:

\begin{tabular}{|c|c|c|c|}
\hline & $\begin{array}{l}\text { Treatment } \\
\text { no. }\end{array}$ & Initial diet & Basal diet \\
\hline Expt I & $\left.\begin{array}{l}36 \\
37\end{array}\right\}$ & $400 \mathrm{ml}$ separated colostrum & $\left\{\begin{array}{l}\text { Whole milk } \\
\text { Whole milk + oestradiol }\end{array}\right.$ \\
\hline Expt 2 & $\left.\begin{array}{l}3^{8} \\
39\end{array}\right\}$ & $400 \mathrm{ml}$ separated colostrum & $\left\{\begin{array}{l}\text { Whole milk } \\
\text { Whole milk + stilboestrol }\end{array}\right.$ \\
\hline
\end{tabular}

Shorthorn bull calves were used in Expt I ; in Expt 2 six blocks consisted of Shorthorn bull calves and six of Ayrshires.

\section{Diets}

Basal diet. The calves were reared on bulked whole milk from the Institute herd for 3 weeks; the daily allowance was $\mathrm{I} \mathrm{lb} /$ ro lb live weight, except when scouring occurred (see below).

Separated colostrum. Batches of separated colostrum were prepared and stored by the method of Aschaffenburg et al. (1953). Four batches in equal volume were blended so that each calf received $400 \mathrm{ml}$ as its first meal within $12 \mathrm{~h}$ of birth.

Oestrogen. In Expt I, oestradiol-1 $7 \beta$ (Ciba Laboratories Ltd, Horsham, Sussex) was dissolved in $75 \%(\mathrm{v} / \mathrm{v})$ propylene glycol in water to give a concentration of $93 \mu \mathrm{g} / \mathrm{ml}$. Of this solution $0.5 \mathrm{ml}(46.5 \mu \mathrm{g}$ oestradiol $)$ was given in the milk at the morning feed to calves on treatment 37 , and the control calves received $0.5 \mathrm{ml}$ of the $75 \%$ propylene glycol solvent.

In Expt 2, stilboestrol was dissolved in 81\% propylene glycol to give a concentration of $\mathrm{I} \cdot 5 \mathrm{mg} / \mathrm{ml}$. Of this solution $\mathrm{I} \mathrm{ml} \mathrm{(} \mathrm{I} \cdot 5 \mathrm{mg}$ stilboestrol) was given in the milk at the morning feed to calves on treatment 39 and control calves were given $\mathrm{I} \mathrm{ml}$ of solvent.

\section{Calves}

Collection and management of the calves and treatment at the onset of scouring were as in an earlier experiment (Roy, Shillam, Palmer \& Ingram, I955). Heart rate was measured by auscultation over the chest with a stethoscope, and respiration rate by observation of the flank movements. Both rates were recorded daily, except Sundays, 
at about $\mathrm{i} 2$ noon when the calf was lying down. Heart rates were not recorded until an interval of $30 \mathrm{sec}$ had elapsed from the time the stethoscope had been placed against the chest, since Blaxter (I943) has shown with cows that this action causes a momentary nervous acceleration of the heart rate. In Expt 2, the heart rate was measured twice with an interval of $30 \mathrm{sec}$ between each measurement, and in both experiments duplicate observations were made on each animal by two observers and the mean values recorded.

Teat volumes were obtained at birth and thereafter at weekly intervals in Expt $\mathbf{I}$ and at 4 -day intervals in Expt 2 by measurement of the water displaced by each teat in a graduated glass cylinder.

Blood samples were taken from the jugular vein of all calves in Expt 2 before the first feed, on the ist day and thereafter on alternate days until 3 weeks of age. The erythrocyte count, packed-cell volume (P.C.v.), haemoglobin content, mean corpuscular volume (M.C.v.) and mean corpuscular haemoglobin concentration (M.C.H.C.), and also specific gravity, erythrocyte-sedimentation rate (E.s.R.), fragility of erythrocytes, platelet count, total leucocyte count and differential leucocyte count were determined. The techniques adopted were those used by Greatorex (1954). Blood urea, inorganic phosphate and blood glucose were determined with an M.R.C. Grey-Wedge photometer by procedures adapted from King \& Wootton (I956), and serum sodium and potassium with an E.E.L. (Evans Electroselenium Ltd) flame photometer.

At the end of the experimental period, the rates of oxidation of glucose and acetate by liver slices from nine calves from each of the two treatments in Expt 2 were measured by $\operatorname{Dr}$ R. F. Glascock, using glucose generally labelled with ${ }^{14} \mathrm{C}$ and acetate labelled in the carboxyl group with ${ }^{13} \mathrm{C}$. The use of two isotopes of carbon made it possible to measure the rates of oxidation of the two substrates simultaneously in the same preparation. The apparatus and technique adopted were those used by Duncombe $\&$ Glascock (I956) and described in detail by Glascock (I954) for the study of the rates of oxidation of labelled substrates by mammary tissue. It involved the incubation of $0.5 \mathrm{~g}$ batches of liver slices in isotonic bicarbonate saline to which the labelled substrates had been added, and measurement of the rate of appearance of isotopic carbon in the $\mathrm{CO}_{2}$.

Fresh weights were measured of heart, kidneys, spleen, adrenals, thyroid, thymus, testicles, seminal vesicles, Cowper's glands, prostate (corpus prostatae only) and pituitary gland. Heart weight was not measured for the first three calves on the experiment, and prostate glands were weighed for the last three blocks of calves only.

\section{RESULTS}

\section{Live-weight gain and incidence of scouring}

The results of both experiments are given in Table $\mathrm{I}$. There were no differences in the observed live-weight gains/day between calves given oestrogens and the control animals, but when adjustment was made for the affecting variables, birth weight and total milk consumption, by means of partial regression coefficients given in Table 2 , it was found that stilboestrol significantly $(P<0.05)$ increased weight gain in comparison with the controls. 
Table I. Comparison of the performance of calves given daily supplements of either oestradiol-1 $7 \beta$ or stilboestrol

No. of calves used

Mean birth weight (lb)

Mean milk consumption in $2 \mathrm{I}$ days (pints)

Mean live-weight gain/day (lb)

Adjusted mean live-weight gain/day (lb) $\dagger$

Mean no. of days on which calves scoured

(Mean values with their standard errors)

\begin{tabular}{|c|c|c|c|c|}
\hline \multicolumn{2}{|c|}{ Expt I } & \multicolumn{2}{|c|}{ Expt 2} & \\
\hline \multicolumn{4}{|c|}{ Treatment no. and details } & \\
\hline $\begin{array}{l}36 \\
400 \mathrm{ml} \\
\quad \text { colo }\end{array}$ & $\begin{array}{l}37 \\
\text { parated } \\
\text { um }\end{array}$ & $\begin{array}{l}\begin{array}{l}38 \\
400 \mathrm{ml}\end{array} \\
\quad \mathrm{colc}\end{array}$ & $\begin{array}{l}39 \\
\text { parated } \\
\text { rum }\end{array}$ & \\
\hline $\begin{array}{c}\text { No } \\
\text { oestrogen }\end{array}$ & $\begin{array}{c}46.5 \mu \mathrm{g} \\
\text { oestradiol- } \\
17 \beta \\
\text { daily }\end{array}$ & $\begin{array}{c}\text { No } \\
\text { oestrogen }\end{array}$ & $\begin{array}{c}\text { I·5 mg } \\
\text { stilboestrol } \\
\text { daily }\end{array}$ & $\begin{array}{c}\text { Significance } \\
\text { of } \\
\text { difference } \\
\text { between } \\
\text { treatments }\end{array}$ \\
\hline IO & ro & 12 & 12 & - \\
\hline $83 \cdot 6 \pm 3 \cdot 4$ & $79.0 \pm 3.4$ & $73 \cdot 0 \pm 8.7$ & $76 \cdot 9 \pm 8 \cdot 7$ & - \\
\hline $13^{8 \cdot 6 \pm 6 \cdot 0}$ & $126 \cdot 6 \pm 6 \cdot 0$ & $1 \times 7 \cdot 1 \pm 4 \cdot 1$ & $x+6 \cdot 7 \pm 4^{\cdot 1}$ & - \\
\hline $0.66 \pm 0.06$ & $0.53 \pm 0.06$ & $0.43 \pm 0.08$ & $0.43 \pm 0.08$ & 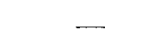 \\
\hline $0.60 \pm 0.03$ & $0.59 \pm 0.03$ & $0.37 \pm 0.04$ & $0.48 \pm 0.04$ & $39>3^{8^{*}}$ \\
\hline $2 \pm 0.6$ & $2 \pm 0.5$ & $3 \pm 0.8$ & $5 \pm x \cdot 4$ & - \\
\hline $46 \cdot 2 \pm 3 \cdot 6$ & $43 \cdot 2 \pm 2 \cdot 7$ & $4 I \cdot I \pm 5 \cdot 0$ & $36 \cdot 9 \pm 3 \cdot 5$ & - \\
\hline- & - & $4 \cdot 7 \pm 2 \cdot 7$ & $6 \cdot 2 \pm x \cdot 2$ & - \\
\hline - & - & $43 \cdot 4 \pm 3 \cdot 6$ & $35 \cdot 7 \pm 2 \cdot 5$ & - \\
\hline$I \pm 0.4$ & $0 \pm 0.2$ & $1 \pm 0.3$ & $I \pm 0.4$ & - \\
\hline $92 \cdot 1 \pm 2 \cdot 4$ & $88 \cdot 6 \pm 2 \cdot 3$ & $8 I \cdot 9 \pm x \cdot 5$ & $83 \cdot 8 \pm 2 \cdot 5$ & - \\
\hline $32 \cdot 5 \pm 5^{\cdot I}$ & $33 \cdot 9 \pm 1 \cdot 9$ & $29.9 \pm 2.0$ & $3 I \cdot 5 \pm 2 \cdot 7$ & - \\
\hline
\end{tabular}

Mean time between birth and complete passage of meconium (h)

Mean time between birth and first feed (h)

Adjusted mean time between birth and complete passage of meconium (h) $\ddagger$

Mean no. of days on which calves had a high rectal temperature $\left(>102 \cdot 8^{\circ} \mathrm{F}\right)$

Mean heart rate (beats $/ \mathrm{min}$ )

Mean respiration rate (respirations/ $\min$ )

* Significant at $P<0.05$. $†$ Adjusted for birth weight and milk consumption.

$\ddagger$ Adjusted for time between birth and first feed.

Table 2. Partial regression coefficients of live-weight gain/day $(l b)$ on birth weight $(l b)$ and total milk consumption (pints) of the calves

\begin{tabular}{|c|c|c|c|c|}
\hline & \multicolumn{2}{|r|}{ Expt I } & \multicolumn{2}{|r|}{ Expt 2} \\
\hline & $\begin{array}{c}\text { General } \\
\text { mean }\end{array}$ & $\begin{array}{l}\text { Partial regression } \\
\text { coefficient with its } \\
\text { standard error }\end{array}$ & $\begin{array}{l}\text { General } \\
\text { mean }\end{array}$ & $\begin{array}{l}\text { Partial regression } \\
\text { coefficient with its } \\
\text { standard error }\end{array}$ \\
\hline Live-weight gain/day (lb) & 0.595 & $\ldots$ & 0.429 & - \\
\hline Birth weight (lb) & $81 \cdot 26$ & $-0.0135 \pm 0.0037^{* *}$ & $74 \cdot 97$ & $-0.0245 \pm 0.0035^{* * *}$ \\
\hline Total milk consumption (pints) & 132.59 & $+0.0153 \pm 0.0019^{* * *}$ & I 16.92 & $+0.0217 \pm 0.0020^{* * *}$ \\
\hline
\end{tabular}


There was very little scouring in Expt I, but in Expt 2, two calves given stilboestrol scoured badly and there was some indication that calves on this treatment tended to scour more than the controls although, owing to the high variance, the difference was not significant. There was a slight indication that calves given stilboestrol passed their meconium more quickly than the controls. The incidence of a high rectal temperature ( $>$ 102. $8^{\circ} \mathrm{F}$ ) was low in both experiments.

\section{Respiration and heart rates}

The salient feature was the high rate at birth with a rapid fall during the ist week of life, followed by a more gradual decline during the next 2 weeks. It was so in all calves except one (calf no. 8 on treatment 39 ), which showed a slight rise in heart rate
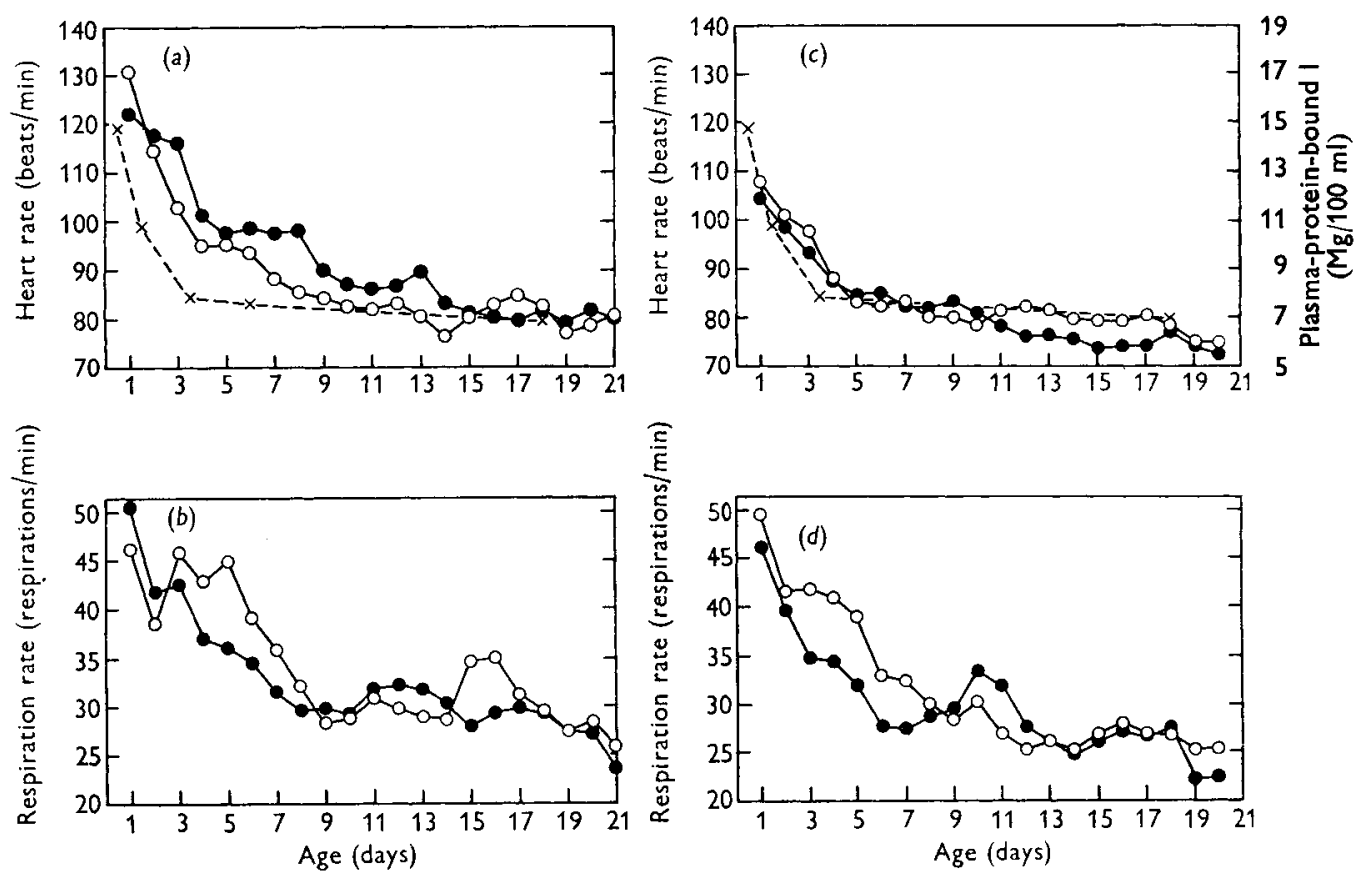

Fig. I. Heart and respiration rates of control (-) and oestrogen-fed $(0-0)$ calves. $\times---\times$, plasma-protein-bound iodine (Lewis \& Ralston, 1953). (a) Expt 1 , heart rate; (b) Expt I, respiration rate; (c) Expt 2, heart rate; $(d)$ Expt 2, respiration rate.

from birth. On the 2 Ist day of life the heart rate of this calf was nearly twice as high as the mean heart rate of all the other calves. The results are shown in Fig. I $a-d$, together with the results of Lewis \& Ralston (1953) for the concentration of plasmaprotein-bound iodine in the calf. For Expt 2, the mean of the two measurements of heart rate is shown; the second measurement averaged $\mathrm{r} \cdot 4$ beats/min less than the first. The mean respiration and heart rates over the 3 -week period are given in Table 1 . Oestrogen treatment had no apparent effect on either measurement, nor was there any relationship between the mean heart rate of individual calves and their body-weight, or between the rate of decline in heart rate and body-weight. 
The mean environmental temperature $\left({ }^{\circ} \mathrm{F}\right)$ in the calfhouse at the time of measurement of these rates, and the mean daily minimum and maximum temperatures, in each experiment, were:

$\begin{array}{lccc} & \text { Minimum } & \begin{array}{c}\text { About } \\ \text { 12 noon }\end{array} & \text { Maximum } \\ \text { Expt 1 } & 56 \cdot 6 & 61 \cdot 6 & 66 \cdot 5 \\ \text { Expt 2 } & 55 \cdot 2 & 60 \cdot 8 & 64 \cdot 5\end{array}$

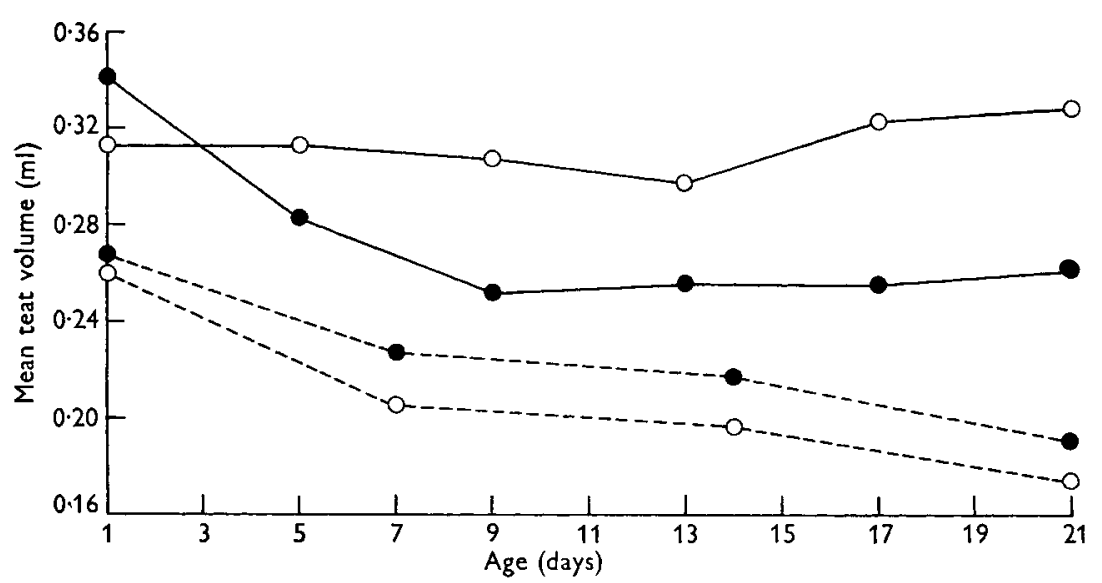

Fig. 2. Mean teat volumes of the experimental calves. Expt I: $\bullet-\cdots$, control; $\bigcirc-\cdots-0,46 \cdot 5 \mu \mathrm{g}$ oestradiol/day. Expt 2: - $\bullet$, control; $0-0,{ }_{1} \cdot 5 \mathrm{mg}$ stilboestrol/day.

Teat volume

The teat volume of all control calves, and of the oestradiol-treated calves in Expt I, declined throughout the 3-week period. However, in Expt 2, stilboestrol supplementation prevented $(P<0.01)$ this decline. The size of a teat at birth significantly affected its reduction in size. Thus, teats large at birth decreased in size more than small ones. The rates of decline in teat volume for the two experiments are shown in Fig. 2. The mean regression coefficients of teat volume on time, together with the initial teat volumes and the mean regression coefficients of teat volume on time adjusted for initial volume, are given in Table 3. To estimate the error attached to the measurement of teat volume, the regression of teat volume on time was calculated for each teat of each calf, and the deviations from regression were pooled. The general mean volumes with their standard deviations from regression in each experiment were:

$\begin{array}{cccc} & \begin{array}{c}\text { General mean } \\ \text { teat volume } \\ (\mathrm{ml})\end{array} & \text { s.D. } & \begin{array}{c}\text { Coefficient of } \\ \text { variation } \\ \text { Expt I }\end{array} \\ \text { Expt 2 } & 0.22 & 0.043 & (\%) \\ & 0.29 & 0.048 & 19.9 \\ & & & 16.6\end{array}$

\section{Blood composition}

Over the 3-week period, specific gravity, P.c.v., erythrocyte count and haemoglobin content fell, but there was a gradual rise in E.s.R., fragility of erythrocytes, platelet count and content of inorganic phosphate. Little apparent change occurred during 


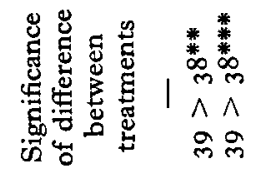
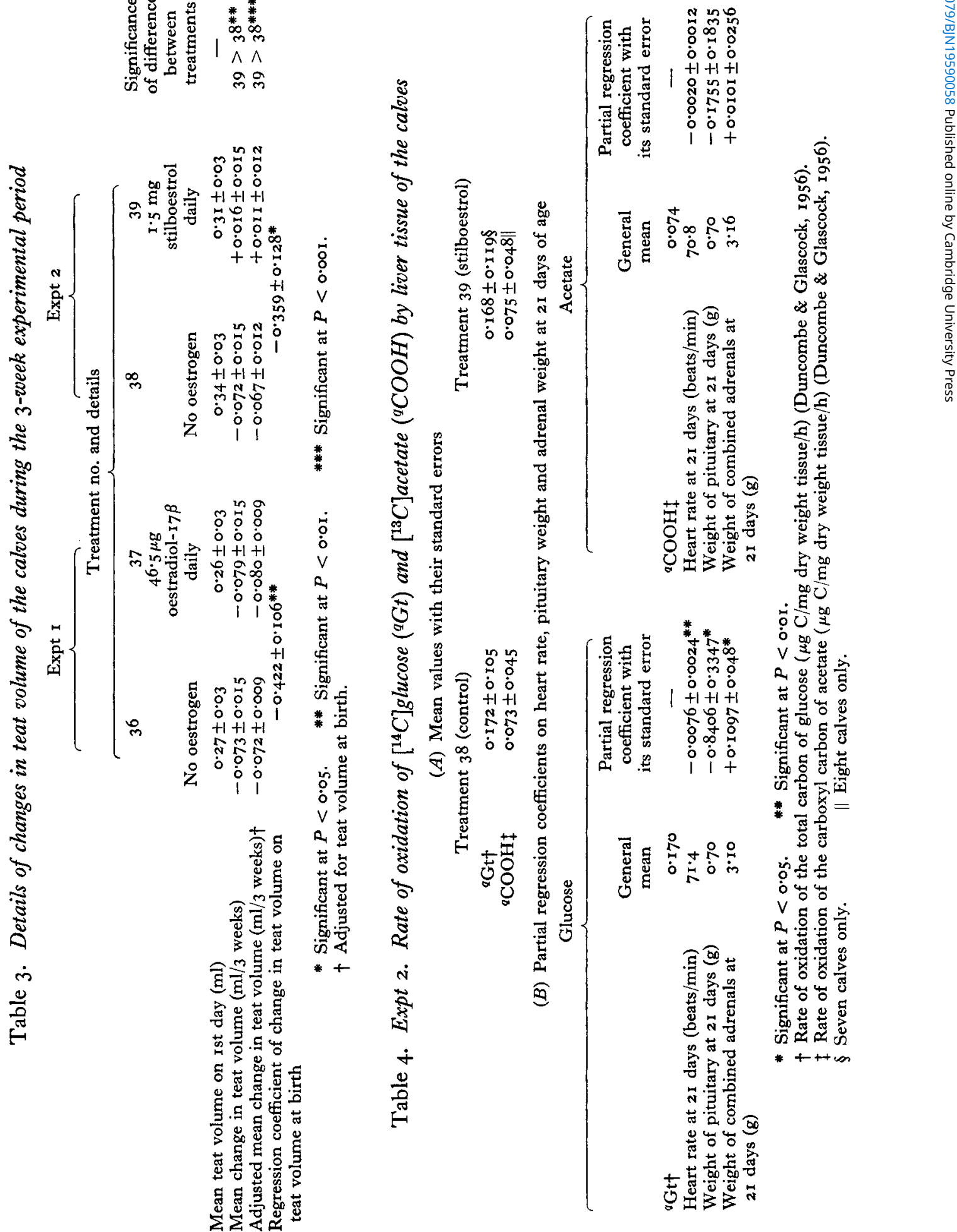
the experimental period in M.c.v., total leucocyte count, M.c.H.C. and content of blood glucose. The percentage of lymphocytes rose markedly during the first 5 days of life with a concomitant fall in the percentage of neutrophils. The blood-urea content appeared to rise slightly during the first 9-I I days of life and thereafter declined. The content of serum potassium increased rapidly after birth and then fell slightly, whereas that of serum sodium fell markedly for the first 7 days of life and then increased gradually throughout the remainder of the experimental period. These results are shown in Fig. 3.

There was no apparent effect of treatment on any of the factors studied, except that stilboestrol feeding appeared to reduce the percentage of lymphocytes with a concomitant increase in the percentage of neutrophils.

\section{Rate of oxidation of $\left[{ }^{14} \mathrm{C}\right]$ glucose and $\left[{ }^{13} \mathrm{C}\right]$ acetate by liver tissue}

The results are given in Table 4. Stilboestrol treatment had no effect on rates of oxidation of either substrate.

Calf no. 8 on treatment 34 had an abnormally high heart rate throughout the experimental period (see p. 45I) and also showed a leucocytosis; the results for this calf were

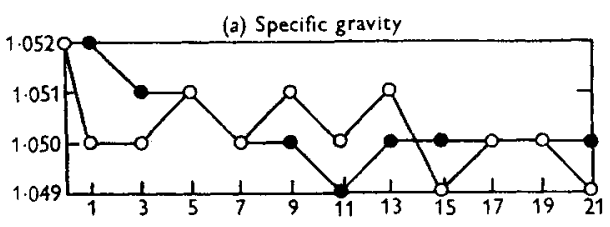

(b) Packed cell volume
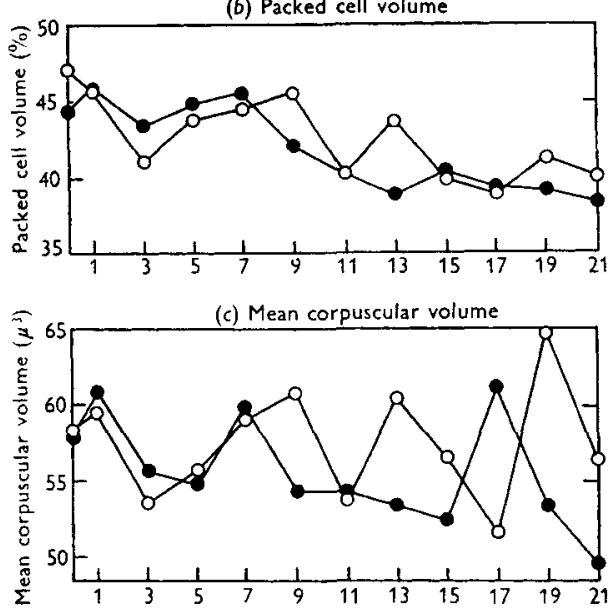

(d) Erythrocyte count

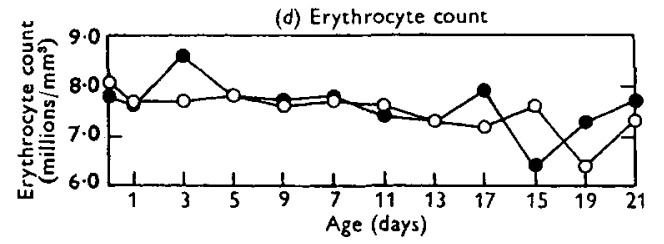

(e) Erythrocyte sedimentation rate
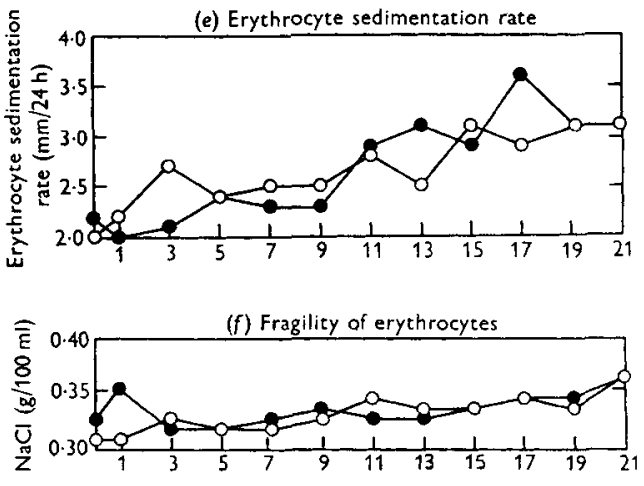

(g) Haemoglobin content
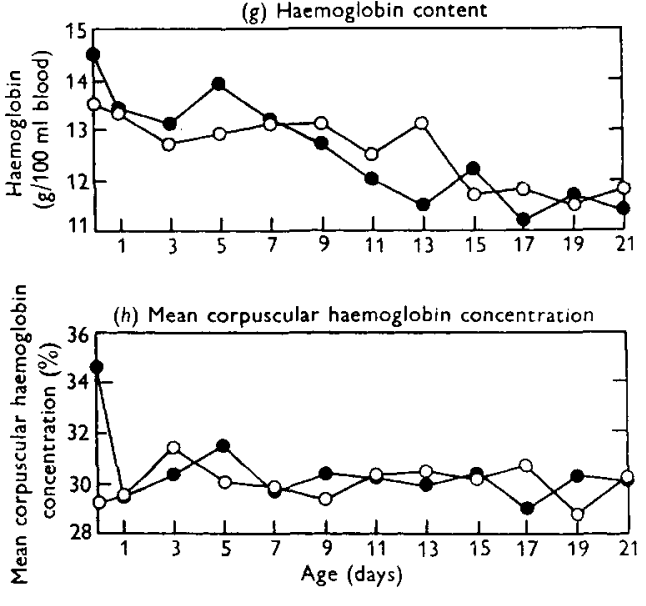

Fig. 3. $a-h$. 

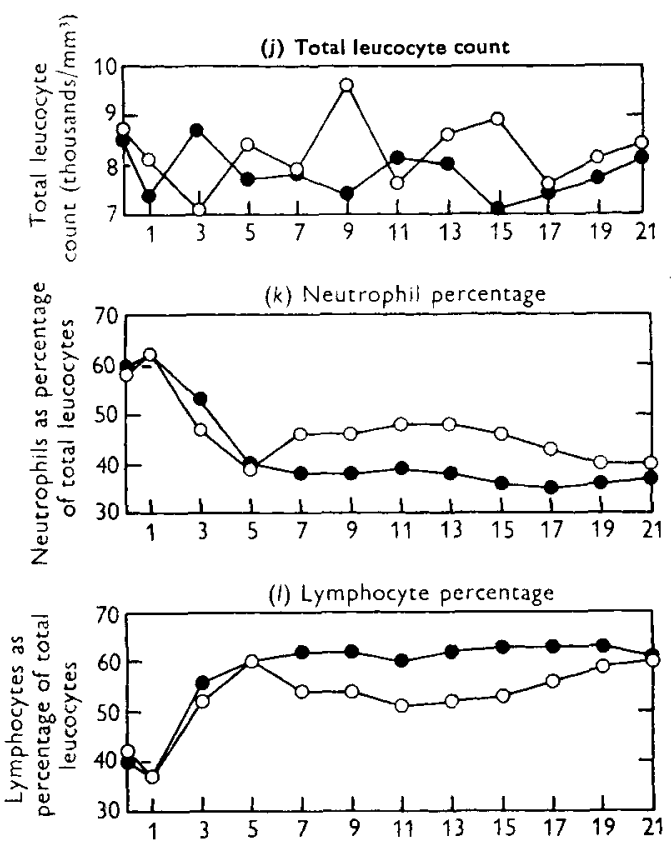

(m) Platelet count

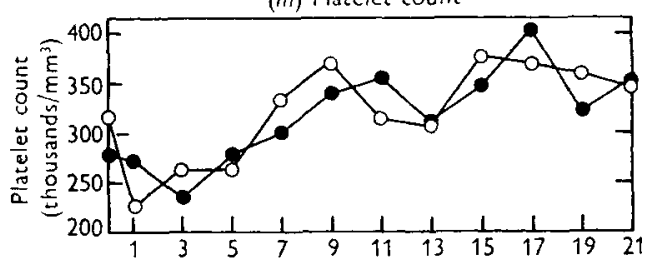

(n) Blood urea content
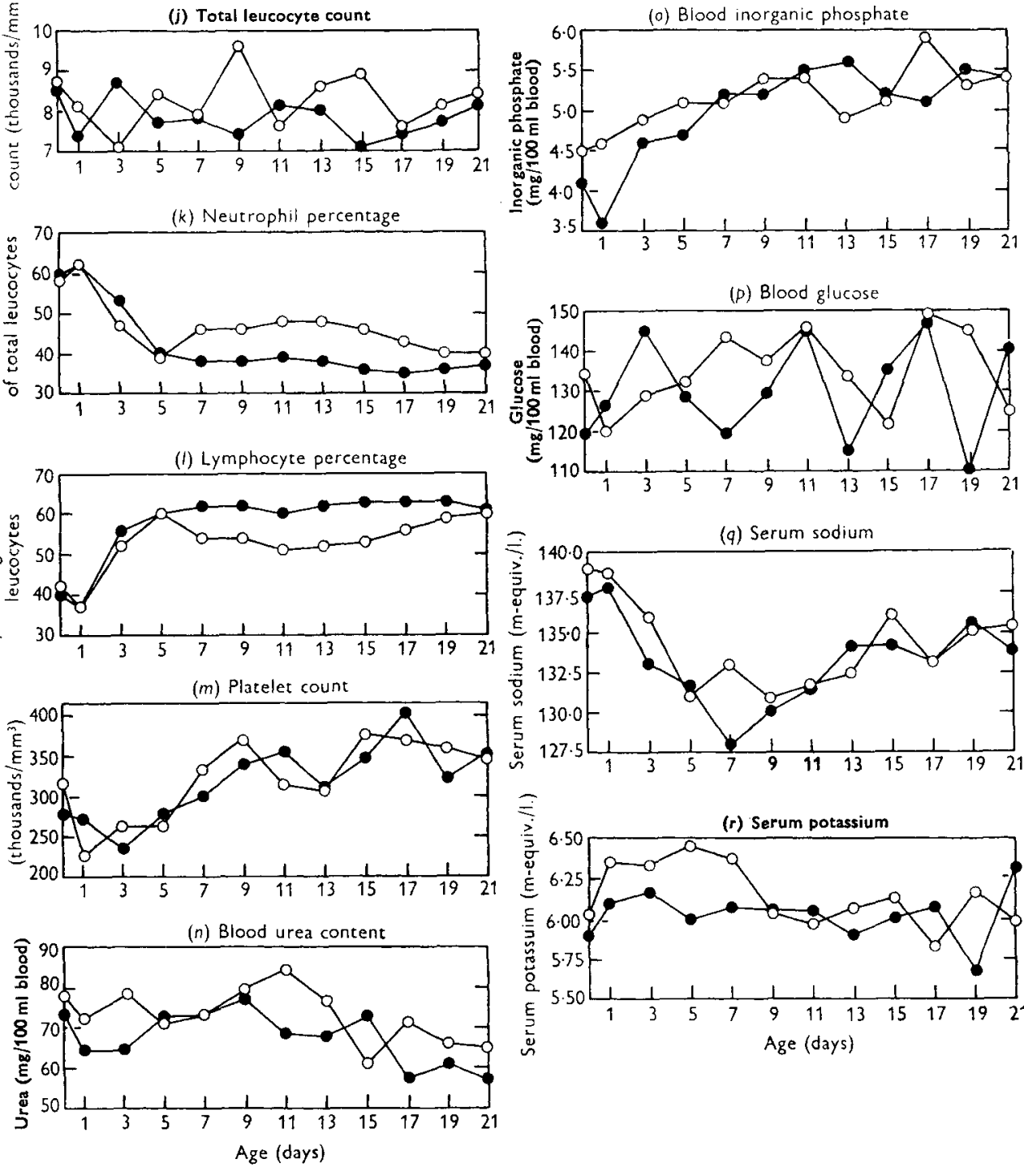

(q) Serum sodium

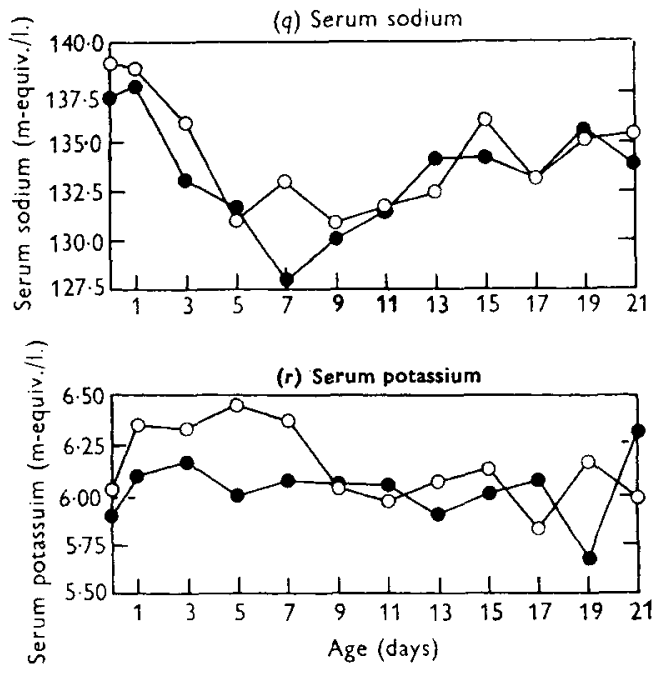

Fig. 3. $j-r$.

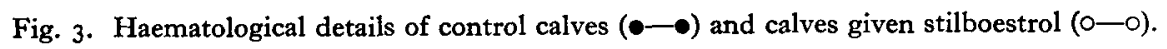

therefore excluded from a multiple covariance analysis of rate of oxidation of substrate carbon by liver tissue on heart rate, weight of pituitary and weight of adrenals. The rate of oxidation of $\left[{ }^{14} \mathrm{C}\right]$ glucose by the liver was negatively related to heart rate $(P<0.01)$ and weight of pituitary $(P<0.05)$ and positively related to weight of adrenals $(P<0.05)$ at the end of the experimental period. The partial regression coefficients are given in Table 4. The leucocyte content of the blood at 21 days was also positively related to heart rate $(P<0.05)$, but the partial regression coefficients of rate of oxidation of $\left[{ }^{14} \mathrm{C}\right]$ glucose on heart rate and on leucocyte content were not significant. 
There was also some indication that the rate of oxidation of $\left[{ }^{13} \mathrm{C}\right]$ acetate was similarly related to heart rate, pituitary and adrenal weight, but the regression coefficients were not significant. No relationship could be shown between respiration rate and the rate of oxidation of either substrate.

\section{Weight of organs}

The mean weights of the various organs from the calves slaughtered at 3 weeks of age in Expt 2 are given in Table 5. Calves that had received stilboestrol had significantly heavier Cowper's glands and seminal vesicles than the control calves. There were no significant differences due to treatment in any of the other organs studied even when the weight of organ was adjusted for differences in body-weight at 3 weeks of age. The weights of all organs, except Cowper's glands, seminal vesicles and prostate, were related to body-weight.

The results of multiple regression analyses showed that the weights of four of the organs, namely thymus, adrenal, thyroid and spleen, were affected not only by bodyweight at 2 I days, but also by the incidence of scouring during the experimental period. The partial regression coefficients of adrenal weight and spleen weight on incidence of scouring were not quite significant but, as one of us (P.L.I.) has observed that the adrenals are enlarged in calves dying from a localized intestinal infection with $E$. coli after profuse scouring, it was considered valid to adjust the treatment means for incidence of scouring. From Table 5 and from histological studies by one of us (P.L.I.), it is apparent that scouring caused enlargement of the adrenals and thyroid, a reduction in size of the spleen and atrophy of the thymus. As one calf (calf no. 7 on treatment 34 ) had one very large abdominal testicle and one scrotal testicle, a replacement value was calculated by the missing-plot technique of Yates (I933).

\section{DISCUSSION}

\section{Live-weight gain and incidence of scouring}

The results of Expt 2 show that over as short a period as 3 weeks $1 \cdot 5 \mathrm{mg}$ stilboestrol given daily by mouth have a physiological effect on the newborn calf. From studies with an artificial rumen and digestibility measurements with ruminating sheep, Brooks, Garner, Muhrer \& Pfander (1954) suggested that the stimulating effect of stilboestrol might be due to increased digestibility of cellulose and protein, but most other workers have been unable to substantiate this finding (Bell, Taylor, Murphree \& Hobbs, 1955; Erwin, Dyer \& Ensminger, I956 b; Jordan, 1953; Jordan \& Bell, 1952; O'Mary, Wilkinson, Wilson, Bray, Pope \& Casida, 1952). Few of our calves showed any signs of rumination before the end of the experimental period, yet a slight improvement in growth rate could be attributed to stilboestrol treatment.

\section{Heart and respiration rates}

The values for heart and respiration rates, although unaffected by oestrogens, are of some interest as we are unaware that the very high rates soon after birth followed by a sharp decline have been previously reported for calves. Dukes (1955), quoting data 


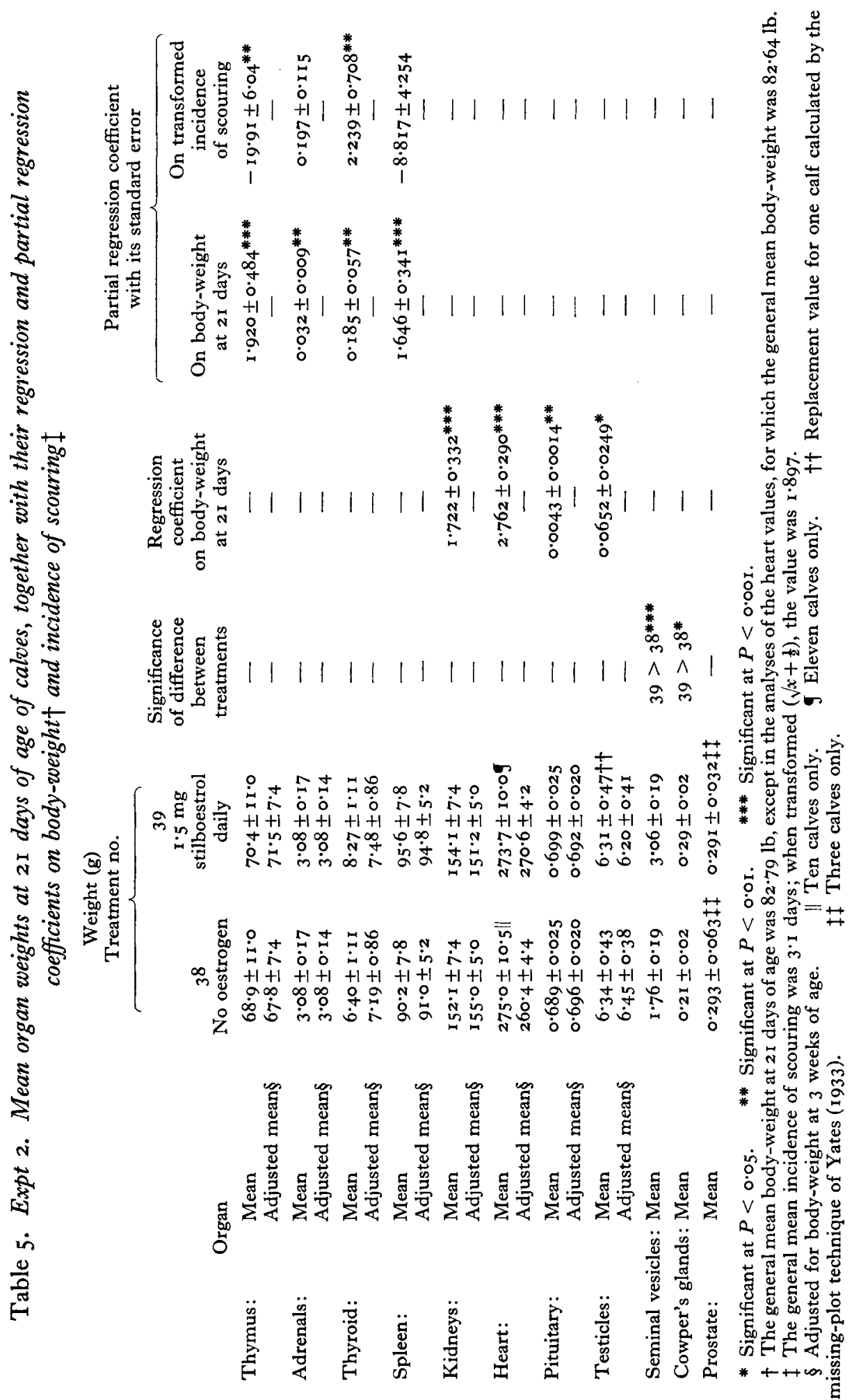


from Ellinger, gives values of II $8-148$ beats/min at birth falling only to IO5-II5 at 8-I4 days and IOO-I I 3 at I month of age, whereas at 3 weeks of age the mean value for our calves was $7 \mathrm{I}$ beats/min. It is possible that the values quoted by Dukes were obtained either with calves not at rest or with those on a very high plane of nutrition, for it is well known that the heart rate is markedly affected by plane of nutrition. Fuller ( 1928 ) noted that for steers on a submaintenance ration, the heart rate was only 33 beats/min against 44 on a maintenance ration and 78 on a fattening ration. A general decline in heart rate of young calves during the progress of an experiment was reported by Blaxter \& Wood (195 I) with values greater than roo beats/min at 5 days of age, declining to $70-85$ at about 30 days. They suggested that this fall was related to a decline in metabolism with advancing age; this view has since been confirmed by experiment (Roy, Huffman \& Reineke, 1957). In keeping with this change in heart rate after birth, Lewis \& Ralston (1953) have demonstrated a fall in plasma-proteinbound iodine from a value of $14.8 \mu \mathrm{g} / 100 \mathrm{ml}$ within $24 \mathrm{~h}$ of birth to $7.6 \mu \mathrm{g}$ at 7 days and 6.9 at $8-30$ days. Their values for plasma-protein-bound iodine, plotted in Fig. I for comparison, are clearly related to our observations of heart rate. The finding that stilboestrol feeding had no significant effect on heart rate in our experiment may possibly be compared with the results of Clegg \& Carroll (1956) who found no increase in serum-protein-bound iodine in steers implanted with stilboestrol, although live-weight gains and weight of seminal vesicles were increased.

There appear to be few published values for the respiration rate of the very young calf, and none that show the marked decrease after birth observed by us. Riek \& Lee (1948) give a mean rate of $2,1 \cdot 2$ respirations/min for Jersey calves 8-17 weeks old at an environmental temperature between 57 and $70^{\circ} \mathrm{F}$ and absolute humidity $2-6 \mathrm{~g} / \mathrm{ft}^{3}$. Blaxter \& Wood (I95 I) give values of 16 respirations $/ \min$ for a 69 -day-old calf at $72^{\circ} \mathrm{F}$ and of 15 and 19 respirations/min for two 34 -day-old calves at $68^{\circ}$ and $63^{\circ} \mathrm{F}$, respectively, obtained during basal-energy determinations after a period of starvation of 24-36 h. The same authors (Blaxter \& Wood, 1952) obtained values of from 21 to 43 respirations/min after starvation for $15 \mathrm{~h}$ of calves given various quantities of milk.

\section{Teat volume}

The large teat volume at birth and subsequent decline in volume have not previously been reported for calves, although it is a well-known phenomenon in the fullterm human infant, in whom the secretion of 'witches milk' often occurs on the $3^{\text {rd }}$ day of life (Forssell, 1938). In our calves there was no sign of any secretion.

The effect of oestrogens in increasing teat size in laboratory animals has been known since 1916 (Steinach \& Holzknecht, $1916 a, b$ ) and, during the last 20 years, similar results have been obtained with farm animals. For example, Folley, Watson \& Bottomley (194I) found that implantation of stilboestrol in castrate male goats caused stimulation of teat growth, whereas in intact male goats teats grew for 3 weeks and then abruptly ceased to grow; the total growth was, however, greater in intact than in castrated goats. Reece (1955) found oestrogens effective in increasing the teat growth of sexually immature heifer calves. 


\section{Blood composition}

The apparent effect of giving stilboestrol on the differential leucocyte count, namely an increase in the percentage of neutrophils, is possibly related to the finding of Moberg (I953) that during the oestrous cycle in adult cows a similar phenomenon occurs.

The well-known effect of oestrogens in reducing the numbers of erythrocytes in laboratory animals and dogs (Burrows, 1949) was not apparent in the results of our erythrocyte counts during the 3-week period. However, Clegg \& Cole (1954) demonstrated reduced haemoglobin levels in stilboestrol-implanted steers, and Wilkinson, Pope, Phillips \& Casida (1954) observed that oestrogen-treated lambs had a lower haematocrit than controls. On the other hand, Erwin, Dyer \& Ensminger (1956a), giving low levels of stilboestrol to steers, found haemoglobin and haematocrit levels unaffected.

Limited information has been available until recently on the blood composition of the newborn calf. Our findings add to those now reported by Greatorex (1954, 1955, r $957 a, b$ ) and Holman (1956).

The gradual increase in fragility of erythrocytes with age found by us agrees with the finding of those workers for normal calves.

The fall in haemoglobin content during the first 2 weeks of life with a tendency for

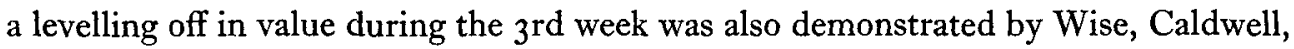
Parrish, Flipse \& Hughes ( 1947), who suggested that at about 4 weeks of age erythropoiesis was activated. Similar results were found by Owen, Voelker, Jacobson $\&$ Allen (1955). However, with calves restricted to an all-milk diet, Wing, Jacobson \& Allen (1955) found a downward trend throughout a 60-day experimental period, a finding similar to that of Thomas, Okamoto, Jacobson \& Moore (1954).

The decrease in erythrocyte count in our calves was similar to that observed by Roberts, Worden \& Evans (1954). The erythrocyte counts obtained by Holman (1956) during the first 3 weeks of life were considerably higher than those found by us; possibly this difference was a reflection of the reduced colostrum intake under the conditions of our experiment.

The low E.S.R. and platelet count at birth and subsequent gradual rise may be compared with the similar findings (reviewed by Smith, 1953) with human infants.

The downward trend in blood urea content with a rise towards the middle of the experimental period would suggest different levels of hydration, for McCance \& Widdowson (1947) have argued that such trends in the newborn infant are related to the limited water intake of early feeding rather than to changes in the amount of exogenous or endogenous nitrogen being metabolized.

There was little change in serum potassium throughout the experimental period, but the high levels during the first 7 days of life of calves given stilboestrol were probably a reflection of the increased incidence of scouring on this treatment (see Roy Shillam, Hawkins, Lang \& Ingram, 1959).

The fall in serum sodium during the Ist week of life of the calf has also been demonstrated by Wise et al. (1947) in normal calves that had received colostrum for 3 days. of Cleoo \& Carroll (1956), who implanted stilboestrol in 


\section{Rate of oxidation of $\left[{ }^{14} \mathrm{C}\right]$ glucose and $\left[{ }^{13} \mathrm{C}\right]$ acetate}

The finding that the rate of oxidation of $\left[{ }^{14} \mathrm{C}\right]$ glucose by the liver was related to the heart rate, pituitary weight and adrenal weight at $2 \mathrm{I}$ days is of some interest. These results may have been fortuitous, although coefficients of the same sign found for $\left[{ }^{13} \mathrm{C}\right]$ acetate would suggest that the results for glucose oxidation were real. Possibly the inverse relationship of rate of glucose oxidation with heart rate could be explained by differences in blood-insulin levels between calves, for it is known that insulin promotes the oxidation of glucose (Marks \& Young, 1939), and in the depancreatized dog the basal metabolic rate is increased. As it is not known to what extent the weight of an endocrine organ can be considered indicative of its amount of secretion, it is not proposed to discuss the significance of the relationship of rate of oxidation of glucose with weights of adrenal and pituitary glands.

\section{Weights of organs}

The effect of oestrogens in increasing the size of accessory reproductive organs of male mice is well known (Lacassagne, 1933; de Jongh, 1933 $a, b, c$; Burrows \& Kennaway, 1934), although in the intact male rat, small doses of stilboestrol over varying periods of time caused a reduction in the weight of seminal vesicles and prostate glands (Matthews, Emery \& Schwabe, 1941; Noble, 1938; Russell, Page, Matthews, Schwabe \& Emery, I941). Our results show that enlargement of the seminal vesicles and Cowper's glands occurs in newborn calves after stilboestrol treatment for only 3 weeks. Similar findings have been demonstrated in lambs and steers (Bell, Smith \& Erhart, 1954; Clegg \& Carroll, 1956; O'Mary, Warren, Davis \& Pierce, 1956; Deans, Van Arsdell, Reineke \& Bratzler, 1956; O’Mary, Pope, Wilson, Bray \& Casida, 1952). We found no evidence of increase in adrenal and pituitary weights in the treated calves, although such evidence has been found in oestrogen-treated rats (Noble, 1938) and steers, bulls and lambs (Clegg, Cole \& Guilbert, 1951; Clegg, Albaugh, Lucas \& Weir, 1955; Cahill, Klosterman, Deatherage \& Kunkle, I954; Cahill, Kunkle, Klosterman, Deatherage \& Wierbicki, I956).

Similarly, there was no indication that the weight of kidneys was increased by stilboestrol feeding as was found by Clegg \& Carroll (1954) with steers, nor was there any evidence of an effect on thyroid size which Clegg \& Cole (1954) and Cahill et al. (I956) found significantly depressed in treated heifers and bulls, although it tended to be increased in treated steers.

The relationship between the weights of certain organs and the incidence of scouring is of interest. It seems probable that the adrenals became enlarged owing to stress and to the disturbance of the electrolyte balance in the calf when prolonged scouring occurred. The concomitant increase in weight of thyroid might be expected, for it is known that the injection of thyroid extract increases the response of an animal to adrenaline injection and it is assumed that the thyroid hormone raises the sensitivity of the structures acted upon by adrenaline (Dukes, 1955).

The related decrease in weight of thymus and spleen was to be expected, for there is already ample evidence of a relation between the adrenal cortex and thymus and 
lymphoid tissue, such as the spleen. Involution of the thymus and lymph nodes has been shown by a number of workers to occur in conditions of adrenal hypertrophy (Jackson, 1915, 1919; McCarrison, 1921; Andersen, 1935; Selye, 1936; Dougherty \& White, 1945; Grégoire, 1946).

\section{SUMMARY}

I. Forty-four newborn bull calves were used in two experiments to find the physiological effect of giving oestradiol-i $7 \beta$ or stilboestrol $(3,4$-di- $p$-hydroxyphenylhex-3-ene) by mouth during the first 3 weeks of life.

2. The variables studied were: live-weight gain, incidence of scouring, incidence of a high rectal temperature $\left(>102.8^{\circ} \mathrm{F}\right)$, rate of passage of meconium, heart rate, respiration rate, teat volume, specific gravity of blood, packed cell volume, mean corpuscular volume, erythrocyte count, erythrocyte sedimentation rate, fragility of erythrocytes, haemoglobin content, mean corpuscular haemoglobin concentration, total and differential leucocyte count, platelet count, content of blood urea, blood inorganic phosphate, blood glucose, serum sodium and potassium, rate of oxidation of $\left[{ }^{14} \mathrm{C}\right]$ glucose, and $\left[{ }^{13} \mathrm{C}\right]$ acetate by the livers of the calves, and weights of thymus, adrenals, thyroid, spleen, kidney, heart, pituitary, testicles, Cowper's glands, seminal vesicles and prostate.

3. A dose of approximately $5 \circ \mu \mathrm{g}$ oestradiol- $\mathrm{I}_{7} \beta$ daily had no obvious effect on the variables studied, whereas a dose of $\mathrm{I} \cdot 5 \mathrm{mg}$ stilboestrol daily resulted in a slightly increased live-weight gain, increased weight of seminal vesicles and Cowper's glands, and prevented a decline in teat volume. There was some indication that stilboestrol caused an increased incidence of scouring. Stilboestrol feeding appeared to increase the percentage of neutrophils.

4. In both treated and control calves, heart rate, respiration rate, packed cell volume, haemoglobin content, erythrocyte count and specific gravity of blood fell throughout the 3 -week experimental period, whereas there was an increase in fragility of erythrocytes, erythrocyte sedimentation rate, platelet count and content of inorganic phosphate. The blood-urea concentration fell gradually except for a sudden rise during the 2nd week. The concentration of serum sodium fell rapidly to the gth day of life and thereafter rose.

5. The weights of all organs were related to the weight of the calf at 2I days, except those of Cowper's glands, seminal vesicles and prostate. The greater the incidence of scouring during the experimental period the greater was the weight of the adrenals and thyroid and the lower was the weight of the thymus and spleen.

6. The rate of oxidation of $\left[{ }^{14} \mathrm{C}\right]$ glucose by the livers of the calves was inversely related to the heart rate and pituitary weight and positively related to adrenal weight on the 21st day of life. A similar trend was indicated for the oxidation of $\left[{ }^{13} \mathrm{C}\right]$ acetate. The rates of oxidation of either substrate were unaffected by stilboestrol treatment.

We are indebted to Dr S. Bartlett for his interest in these experiments, to Dr S. J. Folley for his guidance and helpful suggestions, to Dr R. F. Glascock for studying the rates of oxidation of labelled substrates by the livers of the calves and to Dr G. S. Pope for the preparation of the oestrogen supplements. 


\section{REFERENCES}

Andersen, D. H. (1935). F. Physiol. 85, 162.

Aschaffenburg, R., Bartlett, S., Kon, S. K., Roy, J. H. B., Sears, H. J., 'Thompson, S. Y., Ingram, P. L., Lovell, R. \& Wood, P. C. (1953). Brit. $\mathscr{F}$. Nutr. 7, 275.

Bell, T. D., Smith, W. H. \& Erhart, A. B. (1954). F. Anim. Sci. 13, 425.

Bell, M. C., Taylor, J. R., Murphree, R. L. \& Hobbs, C. S. (1955). F. Anim. Sci. r4, I 93.

Blaxter, K. L. (1943). Vet. F. 99, 2.

Blaxter, K. L. \& Wood, W. A. (I95I). Brit. F. Nutr. 5, I I.

Blaxter, K. L. \& Wood, W. A. (1952). Brit. F. Nutr. 6, I.

Brooks, C. C., Garner, G. B., Muhrer, M. E. \& Pfander, W. H. (1954). Science, 120, 455.

Burrows, H. (1949). Biological Action of Sex Hormones, and ed. Cambridge University Press.

Burrows, H. \& Kennaway, N. M. (1934). Amer. F. Cancer, 20, 48.

Cahill, V. R., Klosterman, E. W., Deatherage, F. E. \& Kunkle, L. E. (1954). F. Anim. Sci. 13, 968.

Cahill, V. R., Kunkle, L. E., Klosterman, E. W., Deatherage, F. E. \& Wierbicki, E. (1956). F. Anim. Sci. I5, 7or.

Clegg, M. T., Albaugh, R., Lucas, J. \& Weir, W. C. (1955). F. Anim. Sci. 14, 178.

Clegg, M. T. \& Carroll, F. D. (1954). F. Anim. Sci. 13, 968.

Clegg, M. T. \& Carroll, F. D. (1956). F. Anim. Sci. 15, 37.

Clegg, M. T. \& Cole, H. H. (1954). F. Anim. Sci. r3, 1 88.

Clegg, M. T., Cole, H. H. \& Guilbert, H. R. (1951). F. Anim. Sci. ro, 1074.

Deans, R. J., Van Arsdell, W. J., Reineke, E. P. \& Bratzler, L. J. (1956). F. Anim. Sci. 15, 1020.

de Jongh, S. E. (1933a). Acta brev. neerl. Physiol. 3, 52.

de Jongh, S. E. (1933b). Acta brev. neerl. Physiol. 3, 88.

de Jongh, S. E. (1933c). Acta brev. neerl. Physiol. 3, I 12.

Dougherty, T. E. \& White, A. (1945). Anat. Rec. 9r, 269.

Dukes, H. H. (1955). Physiology of Domestic Animals, 7 th ed. London: Baillière, Tindall and Cox.

Duncombe, W. G. \& Glascock, R. F. (1956). Biochem. F. 63, 326.

Erwin, E. S., Dyer, I. A. \& Ensminger, M. E. (1956a). Ұ. Anim. Sci. 15, 7 ro.

Erwin, E. S., Dyer, I. A. \& Ensminger, M. E. (1956b). Ұ. Anim. Sci. 15, 717 .

Folley, S. J., Watson, H. M. S. \& Bottomley, A. C. (1941). F. Dairy Res. 12, 24 I.

Forssell, P. (1938). Acta paediat., Stockh., 23, Suppl. 1, p. I.

Fuller, J. M. (1928). Tech. Bull. N. H. agric. Exp. Sta. no. 35.

Glascock, R. F. (1954). Isotopic Gas Analysis for Biochemists. New York: Academic Press Inc.

Greatorex, J. C. (1954). Brit. vet. F. 110, 120.

Greatorex, J. C. (1955). Brit. vet. $\mathcal{F}$. III, 300.

Greatorex, J. C. (1957a). Brit. vet. F. 113, 29.

Greatorex, J. C. (1957b). Brit. vet. F. 113, 65.

Grégoire, C. (1946). F. Endocrinol. 5, 68.

Harris, B. \& Rusoff, L. L. (1956). Ұ. Dairy Sci. 39, 929.

Holman, H. H. (1956). Brit. vet. F. rr2, 9 r.

Jackson, C. M. (1915). F. exp. Zool. 19, 99.

Jackson, C. M. (1919). Amer. F. Anat. 25, 22 I.

Jordan, R. M. (1953). F. Anim. Sci. 12, 670.

Jordan, R. M. \& Bell, T. D. (1952). F. Anim. Sci. rr, 795.

King, E. J. \& Wootton, I. D. P. (1956). Micro-analysis in Medical Biochemistry, 3rd ed. London: J. and A. Churchill.

Lacassagne, A. (1933). C.R. Soc. Biol., Paris, 113, 590.

Lewis, R. C. \& Ralston, N. P. (1953). F. Dairy Sci. 36, 363 .

McCance, R. A. \& Widdowson, E. M. (1947). Lancet, 252, 787 .

McCarrison, R. (1921). Studies in Deficiency Diseases. Oxford University Press.

Marks, H. P. \& Young, F. G. (1939). F. Endocrinol. 1, 470.

Matthews, C. S., Emery, F. E. \& Schwabe, E. L. (1941). Endocrinology, 28, 76r.

Moberg, R. (1953). Proc. int. vet. Congr. xv. Stockholm, 2, part 1, p. 755.

Noble, R. L. (1938). F. Physiol. 94, 177.

O'Mary, C. C., Pope, A. L., Wilson, G. D., Bray, R. W. \& Casida, L. E. (1952). F. Anim. Sci. I1, 656.

O'Mary, C. C., Warren, E. P., Davis, T. J. \& Pierce, H. H. (1956). F. Anim. Sci. 15, 52.

O'Mary, C. C., Wilkinson, W. S., Wilson, G. D., Bray, R. W., Pope, A. L. \& Casida, L. E. (1952). F. Anim. Sci. II, 75I.

Owen, F. G., Voelker, H. H., Jacobson, N. L. \& Allen, R. S. (1955). F. Dairy Sci. 38, 89г .

Pope, G. S. \& Roy, J. H. B. (1953). Biochem. F. 53, 427.

Reece, R. P. (1955). F. Dairy Sci. 38, 609.

Riek, R. F. \& Lee, D. H. K. (1948). F. Dairy Res. $15,227$. 
Roberts, H. E., Worden, A. N. \& Evans, E. T. R. (1954). F. comp. Path. 64, 283.

Roy, J. H. B., Huffman, C. F. \& Reineke, E. P. (1957). Brit. F. Nutr. xx, 373.

Roy, J. H. B., Shillam, K. W. G., Hawkins, G. M., Lang, J. M. \& Ingram, P. L. (1959). Brit. F. Nutr. I3, 219 .

Roy, J. H. B., Shillam, K. W. G., Palmer, J. \& Ingram, P. L. (1955). Brit. F. Nutr. 9, 94.

Russell, H. K., Page, R. C., Matthews, C. S., Schwabe, E. L. \& Emery, F. E. (194r). Endocrinology, 28, 897 .

Selye, H. (1936). Brit. F. exp. Path. r7, 234.

Smith, C. A. (1953). Physiology of the Newborn Infant, and ed. Springfield, Ill.: C. C. Thomas.

Steinach, E. \& Holzknecht, G. (1916a). Arch. Entw Mech. Org. 42, 307.

Steinach, E. \& Holzknecht, G. (1916b). Arch. EntwMech. Org. 42, 490.

Thomas, J. W., Okamoto, M., Jacobson, W. C. \& Moore, L. A. (1954). F. Dairy Sci. 37, 805.

Voelker, H. H. \& Dracy, A. E. (1956). F. Dairy Sci. 39, 929.

Wilkinson, W. S., Pope, A. L., Phillips, P. H. \& Casida, L. E. (1954). F. Anim. Sci. 13, 684.

Wing, J. M., Jacobson, N. L. \& Allen, R. S. (1955). F. Dairy Sci. 38, roo6.

Wise, G. H., Caldwell, M. J., Parrish, D. B., Flipse, R. J. \& Hughes, J. S. (1947). F. Dairy Sci. 30, 983.

Yates, F. (1933). Emp. F. exp. Agric. 1, 129.

\title{
The effect of giving stilboestrol and chlortetracycline to colostrum-fed calves
}

\author{
By JILL M. LANG, J. H. B. ROY AND K. W. G. SHILLAM \\ National Institute for Research in Dairying, Shinfield, Reading \\ AND P. L. INGRAM \\ Department of Pathology, Royal Veterinary College, Camden Town, \\ London, N.W. I
}

(Received 13 April 1959)

In an earlier paper, Hawkins, Roy, Shillam, Greatorex \& Ingram (1959) showed that r. $5 \mathrm{mg}$ stilboestrol given daily by mouth significantly increased the growth rate of newborn calves, although it appeared to increase slightly the incidence of scouring. As Roy, Shillam, Palmer \& Ingram (I955) have shown that chlortetracyline reduced the incidence of scouring and increased weight gain of colostrum-deprived calves, it seemed probable that chlortetracycline and stilboestrol when given together to calves might produce an increase in live-weight gain greater than that obtained with either supplement alone.

An earlier experiment (Ingram, Shillam, Hawkins \& Roy, 1958) was planned to study the protective action of antibiotics against Escherichia coli septicaemia, the usual post-mortem finding in calves that die after having been deprived of colostrum. In the experiment reported here all calves were given initially a small amount of colostrum to give protection against this septicaemic form of white scours. Information could thus be obtained on the value of chlortetracycline in protecting calves from death associated with an $E$. coli localized intestinal infection (Wood, I955), the usual post-mortem finding in those colostrum-fed calves that die. 